\title{
Application of Advanced Reservoir Characterization, Simulation, and Production Optimization Strategies to Maximize Recovery in Slope, and Basin Clastic Reservoirs, West Texas (Delaware Basin)
}

\author{
Quarterly Report \\ January 1 - March 31, 1997
}

By:
Shirley P. Dutton

Work Performed Under Contract No.: DE-FC22-95BC14936

For

U.S. Department of Energy

Office of Fossil Energy

Federal Energy Technology Center

P.O. Box 880

Morgantown, West Virginia 26507-0880

By

Bureau of Economic Geology

The University of Texas at Austin

University Station, Box X

Austin, Texas 78713-7508 


\section{Disclaimer}

This report was prepared as an account of work sponsored by an agency of the United States Government. Neither the United States Government nor any agency thereof, nor any of their employees, makes any warranty, express or implied, or assumes any legal liability or responsibility for the accuracy, completeness, or usefulness of any information, apparatus, product, or process disclosed, or represents that its use would not infringe privately owned rights. Reference herein to any specific commercial product, process, or service by trade

name, trademark, manufacturer, or otherwise does not necessarily constitute or imply its endorsement, recommendation, or favoring by the United States Government or any agency thereof. The views and opinions of authors expressed herein do not necessarily state or reflect those of the United States Government or any agency thereof. 


\section{TECHNICAL PROGRESS REPORT}

Title:

Cooperative Agreement No.:

Institution:

Date of Report:

Award Date:

Anticipated Completion Date for this Budget:

Government Award for this Budget Period:

Program Manager:

Principal Investigator:

Contracting Officer's Representative:

Reporting Period:
APPLICATION OF ADVANCED RESERVOIR

CHARACTERIZATION, SIMULATION, AND PRODUCTION OPTIMIZATION STRATEGIES TO MAXIMIZE RECOVERY IN SLOPE AND BASIN CLASTIC RESERVOIRS, WEST TEXAS (DELAWARE BASIN)

DE-FC22-95BC14936

Bureau of Economic Geology

The University of Texas at Austin University Station, Box $X$

Austin, Texas 78713-7508

April 30, 1998

March 31, 1995

J une 30, 1998

$\$ 1,010,208$

J erry Casteel

Shirley P. Dutton

J erry Casteel

January 1, 1998 - March 31, 1998 


\section{OBJ ECTIVES}

The objective of this project is to demonstrate that detailed reservoir characterization of slope and basin clastic reservoirs in sandstones of the Delaware Mountain Group in the Delaware Basin of West Texas and New Mexico is a cost effective way to recover a higher percentage of the original oil in place through strategic placement of infill wells and geologically based field development. Project objectives are divided into two major phases. The objectives of the reservoir characterization phase of the project were to provide a detailed understanding of the architecture and heterogeneity of two fields, the Ford Geraldine unit and Ford West field, which produce from the Bell Canyon and Cherry Canyon Formations, respectively, of the Delaware Mountain Group and to compare Bell Canyon and Cherry Canyon reservoirs. Reservoir characterization utilized 3-D seismic data, high-resolution sequence stratigraphy, subsurface field studies, outcrop characterization, and other techniques. Once the reservoircharacterization study of both fields was completed, a pilot area of approximately $1 \mathrm{mi}^{2}$ in one of the fields was chosen for reservoir simulation.

The objectives of the implementation phase of the project are to (1) apply the knowledge gained from reservoir characterization and simulation studies to increase recovery from the demonstration area, (2) demonstrate that economically significant unrecovered oil can be recovered by a $\mathrm{CO}_{2}$ flood of the demonstration area, and (3) test the accuracy of reservoir characterization and flow simulation as predictive tools in resource preservation of mature fields. A geologically designed, enhanced-recovery $\mathrm{CO}_{2}$ flood and well-completion program will be developed. Through technology transfer workshops and other presentations, the knowledge gained in this study can then be applied to increase production from the more than 100 other Delaware Mountain Group reservoirs.

\section{SUMMARY OF TECHNICAL PROGRESS}

\section{Technology Transfer}

A poster and core display about slope and basin clastic reservoirs at Geraldine Ford field was presented at the Sixth Archie Conference in Kerrville, Texas, in February. The following abstract was distributed to the conference participants:

Dutton, S. P., Asquith, G. B., and Malik, M. A., 1998, Incorporation of core data into reservoir characterization of a deep-water channel-levee and lobe deposit, Ford Geraldine Unit, Delaware Basin (abs.): Sixth Archie Conference, Kerrville, TX.

A core and poster display was presented at the Permian Basin Section-SEPM meeting "Permian Basin Core Workshop-DOE Funded Reservoir Characterization Projects" in Midland in February. The following paper was published in the meeting transactions:

Dutton, S. P., Barton, M. D., Clift, S. J ., and Guzman, J. I., 1998, Ramsey sandstone deep-water channel-levee and lobe deposits, Ford Geraldine Unit, Reeves and Culberson Counties, Texas: in Stoudt, E. L., Dull, D. W., and Raines, M. R., eds., Permian Basin Core Workshop-DOE Funded Reservoir Characterization Projects: Permian Basin SectionSEPM Publication No. 98-40, 33 p. 
A talk was presented at the SPE Permian Basin Oil and Gas Recovery Conference in Midland in March. The following paper was published in the meeting transactions:

Malik, M. A., 1998, Compositional simulations of a $\mathrm{CO}_{2}$ flood in Ford Geraldine Unit, Texas: SPE paper 39794, presented at 1998 SPE Permian Basin Oil and Gas Recovery Conference, Midland, TX, March 23-26, 1998, p. 375-383.

\section{PLANNED ACTIVITIES}

Conoco, Inc., the industry partner for this project through December, 1997, has decided not to proceed to a Phase 2 field demonstration in the Ford Geraldine unit. The decision by Conoco, Inc. not to proceed to Phase 2 provides an opportunity for a different, and more definitive, Phase 2 field demonstration in East Ford field, with Orla Petco as the industry partner. Orla Petco, Inc. is the operator of East Ford field, which is immediately adjacent to the Ford Geraldine unit and produces from the same Ramsey sandstone channel. The Bureau and Orla Petco propose to work together in Phase 2, thus allowing the original objectives-assessment of the effectiveness of $\mathrm{CO}_{2}$ flooding to improve recovery in a mature Ramsey sandstone field-to be accomplished.

Reservoir characterization of East Ford field will be necessary before moving to the fielddemonstration phase. Reservoir characterization of this new field will provide an excellent opportunity to test the transferability of the information and methodologies that were developed during the Ford Geraldine study to another Delaware Mountain Group field with less abundant data. It is anticipated that information on depositional processes, geometries, and dimensions of Bell Canyon sandstone bodies developed from the outcrop study will apply to Ford East field equally well as to the reservoirs at the Ford Geraldine unit. Furthermore, the methods of petrophysical analysis developed to work with the 1950's vintage logs from the Ford Geraldine unit should be applicable in East Ford field as well. A revised statement of work will be submitted in the next quarter that will propose this revision in the scope of work for the project. 